\title{
Effect of Different Treatments on Nutritional Value of Lima Bean (Phaseolus lunatus) and Its Utilization in Biscuit Manufacture
}

\author{
Sahar S. El-Gohery \\ Bread and Pasta Department, Food Technology Research Institute, Agricultural Research Center, Giza, Egypt \\ Email: sahar_elgohery@hotmail.com
}

How to cite this paper: El-Gohery, S.S. (2021) Effect of Different Treatments on Nutritional Value of Lima Bean (Phaseolus lunatus) and Its Utilization in Biscuit Manufacture. Food and Nutrition Sciences, 12, 372-391.

https://doi.org/10.4236/fns.2021.124029

Received: March 8, 2021

Accepted: April 19, 2021

Published: April 22, 2021

Copyright $\odot 2021$ by author(s) and Scientific Research Publishing Inc. This work is licensed under the Creative Commons Attribution International License (CC BY 4.0).

http://creativecommons.org/licenses/by/4.0/

\begin{abstract}
Physical properties, chemical composition, minerals content, amino acids profile and anti-nutritional factors i.e. phytic acid, tannins and trypsin inhibitor of lima bean seeds (Phaseolus lunatus) which newly cultivated in Egypt were investigated. Addition to study the effect of common processing methods (soaking, cooking, roasting, and dehulling) on the chemical composition, minerals content and anti-nutritional factors of lima bean seeds in order to be used in biscuit preparation. Results showed that protein content was significantly $(P \leq 0.05)$ increased in dehulled Lima bean $(27.06 \%)$ compared to raw lima bean $(26.02 \%)$. All processing methods significantly $(P \leq 0.05)$ increased Soluble Dietary Fiber (SDF), however soaked seeds contained the highest significant Total Dietary Fiber (TDF) (30.18\%) and Insoluble Dietary Fiber (IDF) (22.15\%). Raw lima bean was superior in calcium, iron, magnesium, sodium, potassium, copper, and zinc compared with all processed samples. Raw lima bean had a higher content of all essential amino acids, except methionine compared to wheat flour of $72 \%$ extraction rate. The effect of different processing methods used in this study on lowering phytic acid and tannins, was arranged in the following significant $(P \leq 0.05)$ order: dehulling $>$ cooking $>$ roasting $>$ soaking. Trypsin inhibitor was completely eliminated by cooking and dehulling treatments. Results showed that no significant differences $(P \leq 0.05)$ were found in appearance, color, texture and overall acceptability of substituted with $30 \%$ raw or processed lima bean and between control biscuit (100\% wheat flour). The diameter, spread ratio, chemical composition (protein, ash, crude fiber, SDF, IDF and TDF) and minerals were significantly increased in all substituted biscuits compared to control biscuit. Improvement in the essential amino acid profile of raw Lima biscuit was observed with higher values of essential amino acids, Chemical Score (CS), and Biological Value (BV). This study recommended the use of lima
\end{abstract}


bean in preparing biscuits at $30 \%$ replacement to enhance the nutritional composition of biscuits with acceptable sensory properties.

\section{Keywords}

Lima Bean, Wheat Flour, Biscuit, Minerals, Amino Acids, Antinutritional Factors

\section{Introduction}

Lima bean (Phaseolus lunatus) is one of the most widely cultivated pulse crops both in the temperate and subtropical regions, it can be grown in a wide range of ecological conditions from warm temperate zones as well as arid and semi-arid tropical regions are common in Africa. The planting season is between April and June and harvesting starts about 5 months after planting [1] [2] [3]. In Egypt lima bean was cultivated at North Delta under the environmental condition of Kafr El-Sheikh Governorate Produced high seed yield 2.5 ton/fed. with about $24 \%$ protein [4].

Lima beans are a good nutritional profile they are very good sources of minerals, dietary fibers and proteins; the seeds have on an average two fold more protein as compared to cereals with more balanced profile of essential amino acids including lysine which is lacking in cereals [5] [6] [7].

Lima beans are low cost dietary vegetables proteins and minerals when compared with animal products, such as meat, fish, and egg. The high fiber content of lima bean helps to reduce spikes in blood sugar after meals. Also, lima bean seeds are rich in bioactive compounds which have health promoting effects [3] [5]. It is possible to say that regular dietary intake of Lima beans may contribute in leading a healthy life [7].

Unfortunately, Lima beans like other legumes, contain some antinutrients such as trypsin inhibitors, phytic acid, oxalate, tannins and cyanide which interfere with absorption and utilization of important minerals as well as reducing protein digestibility and the nutritive value of foods [8] [9] [10].

Inactivation or removal of antinutritional factors will improve the nutritional quality of lima beans and increase their acceptance and utilization as food. Most of antinutritional factors can be completely removed or reduced to a minimal level by common household cooking methods. Some of processing techniques include roasting, cooking, boiling, soaking, autoclaving, germination and dehulling have been reported to remove or reduce antinutritional factors to a desirable level and improving value of Lima bean thereby increasing its utilization in foods and food formulations [7] [11] [12].

Biscuit is one of the most popular processed ready to eat snacks that have possesses several attractive features including wide consumer base, relatively less expensive, more convenient with long shelf-life and have ability to serve as vehicles for important nutrients. It's usually available in different sizes, tastes, and 
shapes. It can also be enriched or fortified with other ingredients to meet specific nutritional or therapeutic needs of consumers [13]. However biscuits can hardly be regarded as a healthy snack because they usually contain high levels of rapidly digested carbohydrate, high fat, generally low levels of fiber and only modest amounts of protein so there is a great need to improve their nutrient value [14] [15].

Legumes have been widely recognized as important sources for fortification of wheat-based traditional bakery products, such as biscuits. Legumes when combined with cereals or grains, a complete protein is achieved. In the developing countries research attention is being paid to better utilization of legumes in addressing protein malnutrition and food security issues. Lima bean has been recognized as a potential supplement or even a substitute for the expensive soy meal and groundnut meal which constitute the major portion of conventional protein source [6] [16] [17]. Accordingly, the present research is focused on determining the physicochemical characteristics and anti-nutritional factors i.e. phytic acid, tannins and trypsin inhibitor in lima bean which newly produced and cultivated in Egypt. In addition to study the effect of common processing methods (cooking, soaking, roasting and dehulled) on its chemical composition and antinutrient content, as well as investigate the possibility of using lima bean powder as a substituted to wheat flour in biscuit production.

\section{Materials and Methods}

\subsection{Materials}

Lima bean (Phaseolus lunatus) was obtained from Forage Research Department, Field Crops Research Institute, Agricultural Research Center, Giza, Egypt. The seeds were harvested of season 2019 (as new cultivated crop in Egypt). The standard solution mixture of different amino acids, Catechin standards, sodium phytate and benzoyl-DL-arginine-p-nitroaniline (BAPA) were obtained from Sigma-Aldrich Chemical Co., St. Louis, USA. All other chemicals were analytical reagent grade. Wheat flour (72\% extraction) was obtained from South Cairo Mills Company, Giza, Egypt. All other ingredients such as sugar, shortening, vanilla, egg, and baking powder were purchased from the local market of Giza, Egypt.

\subsection{Methods}

\subsubsection{Physical Properties of Lima Bean Seeds}

Raw lima bean seeds were manually cleaned to remove foreign matter, broken and immature seeds. Then, seeds subjected to determine physical properties as follows: Seed weight (weight of 100 seeds taken randomly in triplicate, the average reported as 100 seeds weight), seed dimension (length and width) were determined according to the method described by Ibeabuchi et al. [3] seed length and width in mm were measured using a Vernier caliper with accuracy of 0.001 $\mathrm{mm}$ where 10 uniform lima seeds were randomly selected and their length and width were measured, relative density of the seeds was determined according 
to method described by Youssef [18] the increase in volume of $200 \mathrm{ml}$ of distilled water placed in a measuring cylinder after immersing 100 seeds of a known weight. Relative density was calculated according to Equation (1) as follows:

$$
\text { Relative density }=\text { The weight of seed }(\mathrm{gm}) / \text { The volume of seed }(\mathrm{ml})
$$

Hulls and kernel percentages (soaked seeds were separated manually into hulls and kernels, then dried and weighed). Physical properties of lima bean seeds were performed in triplicate.

\subsubsection{Preparation of Lima Bean Powder}

Lima bean powder was prepared according to the method of Jayaalaxmi et al. [12]. The steps used for preparation raw, cooked, soaked, roasted and dehulled lima bean powder were illustrated in Figure 1.

\subsubsection{Chemical Analysis}

\section{1) Chemical composition}

Chemical analysis was performed on raw, cooked, soaked, roasted, dehulled lima bean powder and their respective biscuits. The contents of moisture, protein, fat, crude fiber and ash of raw materials and the biscuits produced were

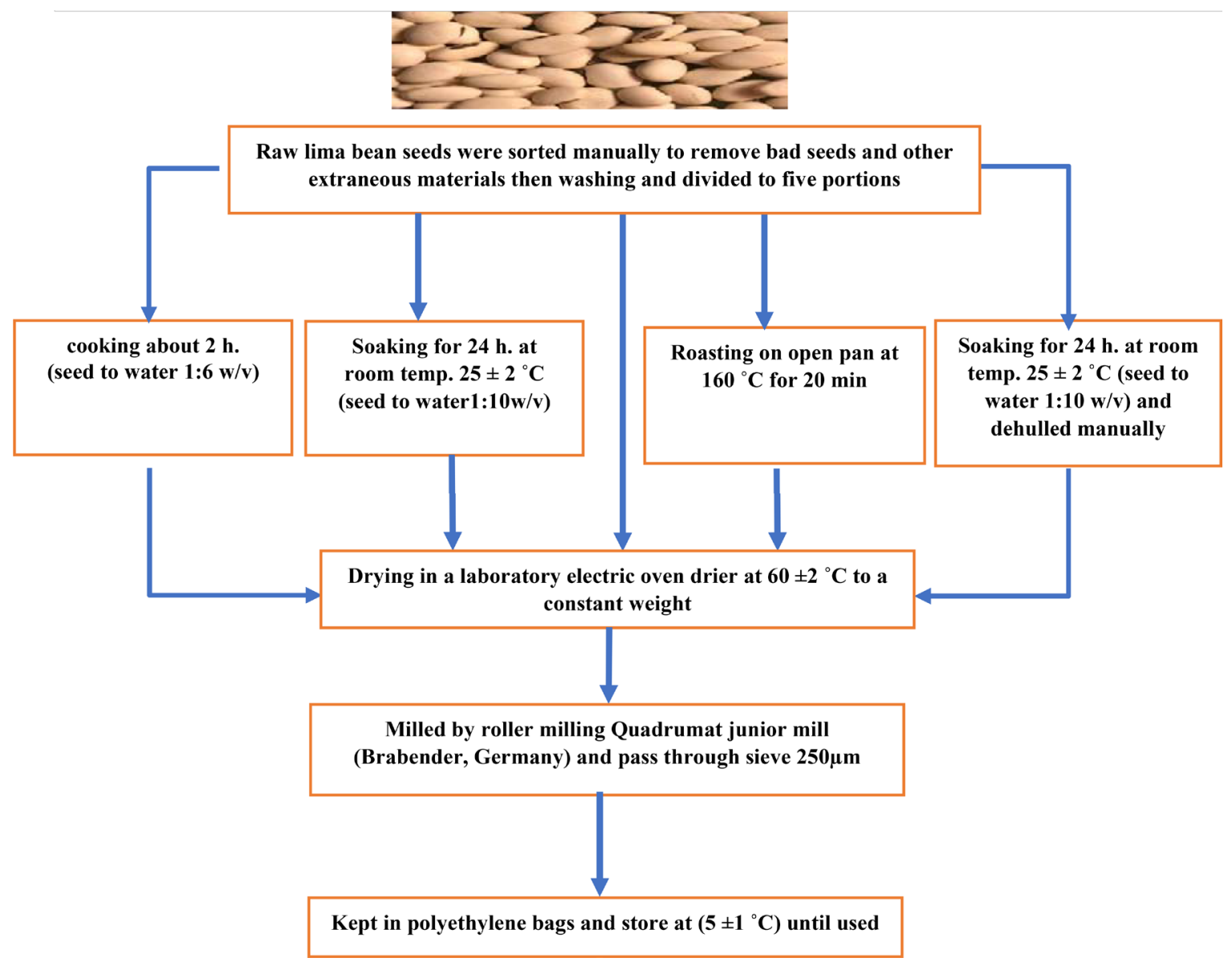

Figure 1. Flow chart for preparation raw, cooked, soaked, roasted and dehulled lima bean powder. 
determined according to the A.O.A.C. [19]. Total carbohydrates were calculated by difference. The energy was calculated from the following Equation (2):

$$
\begin{aligned}
& \text { Energy }(\mathrm{Kcal} / 100 \mathrm{~g}) \\
& =(\% \text { Total carbohydrates } \times 4)+(\% \text { protein } \times 4)+(\% \text { fat } \times 9)
\end{aligned}
$$

Total dietary fiber (TDF) was determined according to A.O.A.C. [20], soluble and insoluble dietary fibers were determined by following the enzymatic method of Prosky et al. [21].

\section{2) Minerals content}

The minerals (calcium $(\mathrm{Ca})$, phosphorous $(\mathrm{P})$, iron $(\mathrm{Fe})$, magnesium $(\mathrm{Mg})$, sodium $(\mathrm{Na})$, potassium $(\mathrm{K})$, copper $(\mathrm{Cu})$, manganese $(\mathrm{Mn})$ and zinc $(\mathrm{Zn}))$ were digested by using microwave digestion system (Multiwave Go Plus) and determined using Microwave Plasma Atomic Emission Spectroscopy (MP-AES) (model 4210, Agilent, Malaysia).

\section{3) Amino acids content}

Amino acid contents of samples were determined using Automatic Amino Acid Analyzer (BIOCHROM 30, serial 103274), according to the method outlined in A.O.A.C. [19]. Chemical score (CS) of essential amino acids (EAA) was calculated using the following equation according to $\mathrm{FAO} / \mathrm{WHO}$ scoring pattern [22] following Equation (3):

$$
\text { Chemical score }(\%)=\text { EAA of crude protein } / \text { EAA of } \mathrm{FAO} / \mathrm{WHO} \times 100
$$

Biological Value (BV) of biscuits was calculated according to Eggum et al. [23] using the following Equation (4):

$$
\mathrm{BV} \%=39.55+8.89 \times \text { lysine }(\mathrm{g} / 100 \mathrm{~g} \text { protein })
$$

\section{4) Anti-nutritional factors}

Phytic acid content was determined according to the method described by Wheeler and Ferrel [24].

Tannins were determined by using the Vanillin-HCL method modified by Price et al. [25]. Catechin was used to prepare the standard curve.

Trypsin Inhibitor Activity (TISA) was measured by the method described by Hamerstrand et al. [26]. The trypsin inhibitor content was determined from the following relationship in Equation (5):

TI mg/g of sample $=$ differential absorbance $/ 0.019 \times 1000 \times$ dilution factor

\subsubsection{Preparation of Biscuits}

A preliminary study was conducted first to choose the highly acceptably percent of lima bean powder for biscuit preparation. Different percent for replacing wheat flour (72\% ext.) with raw lima bean powder at 10\%, 20\%,30\% and $40 \%$. A replacement percent of $30 \%$ lima bean was the most acceptble. Then biscuits were prepared by partially replacing wheat flour with raw or different treated lima bean (cooked, soaked, roasted, or dehulled) powders in the proportions $30 \%$. Biscuits were prepared according to Sayed [27] as follow: The ingredients of biscuits of $100 \mathrm{~g}$ flour, $30 \mathrm{~g}$ butter, $30 \mathrm{~g}$ sugar, $3 \mathrm{~g}$ baking powder, $15 \mathrm{~g}$ eggs, 0.50 
g salt and $1.00 \mathrm{~g}$ vanilla. Butter and sugar were mixed using a Kenwood mixer at a medium speed until a light and fluffy creamy texture was formed, then eggs and vanilla were added, and the mixing process were continued. Wheat flour, lima bean powder and baking powder were slowly added to the mixture, then the biscuits dough was sheeted to $3.5 \mathrm{~mm}$ thickness with the help of an aluminum platform. Circles cut of past pieces were done by using of templates with an outer diameter of $44 \mathrm{~mm}$. The biscuits were baked at $160^{\circ} \mathrm{C}$ for $15 \mathrm{~min}$. Biscuit samples were cooled down at room temperature for 30 minutes after baking until sensory evaluation, then kept in polyethylene bags at refrigerator $4^{\circ} \mathrm{C}$ till further analyses.

\subsubsection{Sensory Evaluation of Biscuits}

Biscuit samples were organoleptically evaluated for their sensory characteristics according to the method of Alsenaien et al. [28] Samples were scored for appearance, color, odor, texture, taste and overall acceptability by ten members of Food Technology Research Institute staff. Agriculture Research Center.

\subsubsection{Physical Characteristics of Biscuits}

The method described by Manohar and Rao [29] was used to evaluate the produced biscuits for weight $(\mathrm{g})$, diameter $(\mathrm{mm})$ and thickness $(\mathrm{mm})$. Weight of biscuit was measured as average values of six individual biscuits by using a digital weighing balance. They were then placed edge-to-edge and stacked one above the other to measure the diameter and thickness respectively, the biscuits were rearranged and restacked and the average of the measurements was taken. The spread ratio and spread factor were calculated using the following Equations ((6), (7)):

Spread ratio $=$ Diameter/Thickness

Spread factor $(\%)=$ Spread ratio of sample/Spread ratio of control $\times 100$

Hardness of biscuits was measured by using a texture analyzer set (Ct3 Texture Analyzer Version 2.1, 10,000 Gram unit Brookfield, Engineering Laboratories, Inc. USA). Hardness was expressed in Newton (N) and automatically recorded by computer software (TA-CT-PRO Software). The samples were compressed to $4 \mathrm{~mm}$ of the original height using TA7Probe, Fixture TA-JTPB, and test speed $2 \mathrm{~mm} / \mathrm{s}$. Water activity $\left(\alpha_{\mathrm{w}}\right)$ of different biscuit samples were measured with a Rotronic Hygro Lab EA10-SCS (Switzerland) $\alpha_{\mathrm{w}}$ meter.

\subsubsection{Statistical Analysis}

The data were analyzed using SPSS 16.0 software. Means and standard deviations were determined using descriptive statistics. Comparisons between samples were determined using analysis of one-way variance (ANOVA) and multiple range tests. Statistical significance was defined at $P \leq 0.05$.

\section{Results and Discussion}

\subsection{Physical Properties of Lima Bean Seeds}

Physical properties of lima bean seeds (weight of 100 seeds, length, width, relative 
Table 1. Physical properties of lima bean seeds.

\begin{tabular}{cc}
\hline Property & Values \\
\hline Seed weight $(\mathrm{g} / 100$ seeds) & $145.16 \pm 0.19$ \\
Length $(\mathrm{mm})$ & $2.14 \pm 0.10$ \\
Width $(\mathrm{mm})$ & $1.46 \pm 0.05$ \\
Relative density $(\mathrm{g} / \mathrm{cm} 3)$ & $1.20 \pm 0.02$ \\
Hull \% & $12.51 \pm 0.09$ \\
Kernels \% & $84.03 \pm 0.11$ \\
\hline
\end{tabular}

Values are means of three replicates \pm standard deviation.

density, hull and kernel percentages) were presented in Table 1 . The values of above measurements were $145.16 \mathrm{~g}, 2.14 \mathrm{~mm}, 1.46 \mathrm{~mm}, 1.20 \mathrm{~g} / \mathrm{cm}^{3}, 12.51 \%$ and $84.03 \%$ respectively.

\subsection{Chemical Composition and Mineral Contents of Lima Bean}

Macro nutrients such as protein, ash, fat, crude fiber, total carbohydrates, energy, soluble and insoluble dietary fibers, total dietary fiber, and mineral contents for raw, cooked, soaked, roasted and dehulled lima bean seeds were shown in Table 2. The results showed that protein content was significantly increased in dehulled lima beans $(27.06 \%)$ compared to raw lima beans (26.02\%), this result may be due to the amount of the removed hulls meaning that $100 \mathrm{~g}$ of crude beans equal $84.03 \mathrm{~g}$ of dehulled beans. On the other hand, protein content was significantly decreased in cooking and soaking treatments $(23.54 \%$ and $24.82 \%$ respectively), lower protein in cooked and soaked beans could be as a result of leaching of soluble components of the protein into the using water [30]. Ash content significantly decreased in cooked, soaked and dehulled lima bean samples with highest significant decrease in dehulled seeds (2.53\%) and this may be as a result of removal seeds hulls. These results were in comparable to the observations stated by D'souza [11]. Also, the reduction in ash content may be due to the leached-out endospermic matter which contains macro and micro elements in the using water. Similar result was given by Jayalaxmi et al. [12] and Farinde et al. [31]. On the other hand, ash content was increased significantly in roasted seeds. Fat content ranged from 2.97 for cooked seeds and 3.65\% for dehulled seeds, there was nonsignificant difference between raw, cooking, and soaking seeds. Also, crude fiber ranged from 1.43 for dehulled seeds and 7.92\% for roasted seeds. Total carbohydrates in raw lima bean were $60.78 \%$; this value was significantly increased with all processing methods except roasting treatment. Agiang et al. [32] suggested that processing softens the cellulose, causes starch granules to break down and makes starch more available. The energy value of raw lima bean was $374.47 \mathrm{Kcal} / 100 \mathrm{~g}$, a similar trend in our study for the effect of processing methods on carbohydrates content was observed with energy values. This suggests that cooked, soaked and dehulled lima bean could be a good 
Table 2. Chemical composition (\%) and mineral contents ( $\mathrm{mg} / 100 \mathrm{~g}$ ) on dry weight basis of lima bean seeds as affected by different processing methods.

\begin{tabular}{|c|c|c|c|c|c|}
\hline \multirow{2}{*}{ Parameters } & \multicolumn{5}{|c|}{ Processing methods } \\
\hline & Raw & Cooking & Soaking & Roasting & Dehulled \\
\hline Protein & $26.02 \pm 0.02^{\mathrm{b}}$ & $23.54 \pm 0.03^{\mathrm{d}}$ & $24.82 \pm 0.04^{\mathrm{c}}$ & $26.04 \pm 0.03^{\mathrm{b}}$ & $27.06 \pm 0.05^{\mathrm{a}}$ \\
\hline Ash & $3.05 \pm 0.04^{\mathrm{b}}$ & $2.73 \pm 0.03^{c}$ & $2.75 \pm 0.05^{c}$ & $3.32 \pm 0.03^{\mathrm{a}}$ & $2.53 \pm 0.02^{\mathrm{d}}$ \\
\hline Fat & $3.03 \pm 0.02^{c}$ & $2.97 \pm 0.02^{c}$ & $3.02 \pm 0.03^{\mathrm{c}}$ & $3.44 \pm 0.03^{\mathrm{b}}$ & $3.65 \pm 0.04^{\mathrm{a}}$ \\
\hline Crude fiber & $7.12 \pm 0.02^{\mathrm{b}}$ & $6.87 \pm 0.02^{c}$ & $6.78 \pm 0.02^{\mathrm{d}}$ & $7.92 \pm 0.02^{\mathrm{a}}$ & $1.43 \pm 0.02^{\mathrm{e}}$ \\
\hline${ }^{*}$ Total carbohydrates & $60.78 \pm 0.13^{\mathrm{d}}$ & $63.89 \pm 0.11^{\mathrm{b}}$ & $62.63 \pm 0.17^{c}$ & $59.28 \pm 0.12^{\mathrm{e}}$ & $65.33 \pm 0.15^{\mathrm{a}}$ \\
\hline Energy (Kcal/100g) & $374.47 \pm 0.17^{\mathrm{d}}$ & $376.45 \pm 0.15^{\mathrm{c}}$ & $376.98 \pm 0.13^{\mathrm{b}}$ & $372.24 \pm 0.15^{\mathrm{e}}$ & $402.41 \pm 0.17^{\mathrm{a}}$ \\
\hline Soluble dietary fiber (SDF) & $6.32 \pm 0.01^{\mathrm{e}}$ & $8.32 \pm 0.03^{\mathrm{b}}$ & $8.03 \pm 0.02^{c}$ & $9.12 \pm 0.02^{\mathrm{a}}$ & $7.14 \pm 0.03^{\mathrm{d}}$ \\
\hline Insoluble dietary fiber (IDF) & $19.52 \pm 0.03^{\mathrm{b}}$ & $19.52 \pm 0.03^{\mathrm{b}}$ & $22.15 \pm 0.04^{\mathrm{a}}$ & $19.02 \pm 0.03^{c}$ & $10.42 \pm 0.03^{\mathrm{d}}$ \\
\hline Total dietary fiber (TDF) & $25.84 \pm 0.05^{\mathrm{d}}$ & $27.84 \pm 0.02^{c}$ & $30.18 \pm 0.05^{\mathrm{a}}$ & $28.14 \pm 0.01^{\mathrm{b}}$ & $17.56 \pm 0.04^{\mathrm{e}}$ \\
\hline Calcium & $360.73 \pm 0.02^{\mathrm{a}}$ & $287.72 \pm 0.03^{\mathrm{d}}$ & $314.87 \pm 0.02^{\mathrm{c}}$ & $342.22 \pm 0.01^{\mathrm{b}}$ & $243.38 \pm 0.02^{\mathrm{e}}$ \\
\hline Phosphorus & $355.63 \pm 0.02^{\mathrm{b}}$ & $323.33 \pm 0.02^{\mathrm{d}}$ & $335.82 \pm 0.02^{c}$ & $362.63 \pm 0.02^{\mathrm{a}}$ & $321.17 \pm 0.02^{\mathrm{e}}$ \\
\hline Iron & $18.54 \pm 0.03^{\mathrm{a}}$ & $15.06 \pm 0.01^{\mathrm{d}}$ & $17.27 \pm 0.02^{\mathrm{b}}$ & $16.92 \pm 0.02^{\mathrm{c}}$ & $12.75 \pm 0.04^{\mathrm{e}}$ \\
\hline Magnesium & $268.04 \pm 0.03^{\mathrm{a}}$ & $248.04 \pm 0.03^{\mathrm{d}}$ & $251.13 \pm 0.02^{c}$ & $257.33 \pm 0.03^{\mathrm{b}}$ & $246.52 \pm 0.02^{\mathrm{e}}$ \\
\hline Sodium & $53.87 \pm 0.02^{\mathrm{a}}$ & $32.88 \pm 0.02^{\mathrm{e}}$ & $39.98 \pm 0.02^{\mathrm{c}}$ & $46.67 \pm 0.02^{\mathrm{b}}$ & $34.03 \pm 0.02^{\mathrm{d}}$ \\
\hline Potassium & $1373.29 \pm 0.15^{\mathrm{a}}$ & $1229.20 \pm 0.12^{\mathrm{e}}$ & $1261.19 \pm 0.17^{\mathrm{d}}$ & $1360.1 \pm 0.10^{\mathrm{b}}$ & $1287.85 \pm 0.14^{\mathrm{c}}$ \\
\hline Copper & $1.74 \pm 0.01^{\mathrm{a}}$ & $1.47 \pm 0.02^{\mathrm{d}}$ & $1.64 \pm 0.01^{\mathrm{b}}$ & $1.62 \pm 0.02^{\mathrm{b}}$ & $1.58 \pm 0.02^{\mathrm{c}}$ \\
\hline Manganese & $1.07 \pm 0.02^{\mathrm{b}}$ & $0.93 \pm 0.02^{\mathrm{e}}$ & $0.98 \pm 0.02^{\mathrm{d}}$ & $1.13 \pm 0.02^{\mathrm{a}}$ & $1.03 \pm 0.02^{\mathrm{c}}$ \\
\hline Zinc & $4.17 \pm 0.02^{\mathrm{a}}$ & $3.74 \pm 0.01^{\mathrm{d}}$ & $3.83 \pm 0.02^{\mathrm{c}}$ & $4.13 \pm 0.03^{\mathrm{b}}$ & $3.63 \pm 0.02^{\mathrm{e}}$ \\
\hline
\end{tabular}

Values are means of three replicates \pm standard deviation, number in the same row followed by the same letter are not significantly different at $P \leq 0.05$. ${ }^{*}$ Total carbohydrates calculated by differences.

source of energy in food formulations [12]. From the values of Total Dietary Fiber (TDF), Soluble Dietary Fiber (SDF) and Insoluble Dietary Fiber (IDF) for raw seeds and seeds after different processing methods it could be observed that, soaked seeds contains the highest percentage of TDF and IDF which amounted in $30.18 \%$ and $22.15 \%$ respectively. All processing methods significantly increased SDF the values ranked as follows: roasted seeds $>$ cooked seeds $>$ soaked seeds $>$ dehulled seeds $>$ raw seeds.

The data for minerals composition per $100 \mathrm{~g}$ of raw lima bean seeds showed that the most abundant mineral was potassium (1373.29 mg), followed by calcium (360.73 mg), phosphorus (355.63 mg), magnesium (268.04 mg), sodium (53.87 mg), iron (18.54 mg), zinc (4.17 mg), copper $(1.74 \mathrm{mg})$ and the least manganese $(1.07 \mathrm{mg})$. Different processing methods observed significant differences in mineral composition between raw and processed seeds. Raw lima bean was superior in calcium, iron, magnesium, sodium, potassium, copper, and zinc compared with all processed samples. But roasted lima was superior in phosphorus and manganese. These results are in agreement nearly with those re- 
ported by Jayalaxmi et al. [12] and Bonita et al. [7] who recorded that lima bean had high mineral content particularly of potassium, phosphors and magnesium, in comparison with cereals, the calcium and iron content were very high in it.

\subsection{Amino Acids Contents}

Amino acid contents of raw lima bean compared with wheat flour ( $72 \%$ ext.) were determined as $\mathrm{g} / 100 \mathrm{~g}$ protein and the obtained results of amino acids are shown in Table 3. Lima bean had a highest content of all essential amino acids except methionine. The low level of methionine recorded is a common phenomenon in legumes. However, this can be overcome by complementing the diet with cereals in which sulphur-amino acids are relatively high [33]. Leucine and lysine were the predominant essential amino acids in Lima, lysine is a major limiting amino acid in most cereals and was presented at $7.97 \mathrm{~g} / 100 \mathrm{~g}$ protein in lima bean. This value is higher than that obtainable in most cereals and can serve

Table 3. Amino acids percentage of raw lima bean and wheat flour $72 \%$ extraction rate ( $\mathrm{g} / 100 \mathrm{gm}$ protein).

\begin{tabular}{|c|c|c|}
\hline Amino Acids & Raw lima bean & Wheat flour ( $72 \%$ ext.) \\
\hline \multicolumn{3}{|c|}{ Essential amino acids } \\
\hline Threonine & 4.87 & 4.32 \\
\hline Valine & 5.73 & 5.01 \\
\hline Isoleucine & 4.67 & 3.92 \\
\hline Leucine & 9.36 & 7.43 \\
\hline Pheneylalanine & 4.14 & 3.98 \\
\hline Tyrosine & 3.68 & 3.32 \\
\hline Lysine & 7.97 & 4.05 \\
\hline Methionine & 1.15 & 2.84 \\
\hline Cystine & 3.93 & 1.98 \\
\hline Histidine & 3.63 & 2.87 \\
\hline TEAA & 49.13 & 39.72 \\
\hline \multicolumn{3}{|c|}{ Non-essential amino acids } \\
\hline Aspartic & 12.94 & 7.79 \\
\hline Serine & 5.52 & 4.56 \\
\hline Glutamic & 13.64 & 20.68 \\
\hline Glycine & 4.63 & 5.31 \\
\hline Alanine & 4.03 & 6.06 \\
\hline Argnine & 6.22 & 5.20 \\
\hline Proline & 3.89 & 10.68 \\
\hline TNEAA & 50.87 & 60.28 \\
\hline
\end{tabular}

${ }^{*}$ Tryptophan was not determined. ${ }^{*}$ TEAA $=$ Total essential amino acids, TNEAA $=$ Total non-essential amino acids. 
as a good complement in diet formulation [34]. Total essential amino acids were higher in Lima bean (49.13 g/100g protein) compared with wheat flour $72 \%$ ext. (39.72 g/100g protein). Also, for non-essential amino acids, lima bean had higher contents of aspartic, serine and arginine values. On the other hand, glutamic, glycine, alanine and proline were higher in wheat flour also, wheat flour had a higher content of total non-essential amino acids $(60.28 \mathrm{~g} / 100 \mathrm{~g}$ protein) compared with lima bean $(50.87 \mathrm{~g} / 100 \mathrm{~g}$ protein).

\subsection{Anti-Nutritional Factors}

Many antinutrients factors are present in legumes, antinutrients reduce the bioavailability of proteins and trace elements. As well, lima bean contains antinutritional factors; most of them can be completely removed or reduced to a minimal level by common household cooking methods. Inactivation or removal of antinutritional factors of lima bean will improve the nutritional quality, increase their acceptance, and enhance effective utilization of it [7]. Table 4 represents the anti-nutrients (phytic acid, tannins and trypsin inhibitor) of lima bean and their levels as influenced by common processing methods (cooking, soaking, roasting and dehulling). Results proved that raw lima beans had the highest values of phytic, tannins and trypsin inhibitor $8.57,5.58$ and $4.28 \mathrm{mg} / \mathrm{g}$ respectively. These values were significantly reduced or completely eliminated due to used different processing methods. The highest reduction of phytic acid and tannins were $92.18 \%$ and $69.18 \%$ respectively due to de-hulling of seeds. Meanwhile, soaked seeds had the lowest reduction of the anti-nutrients. Trypsin inhibitor was completely eliminated by cooking and dehulled treatments whereas soaking and roasting treatments eliminated about $62.15 \%$ and $90.19 \%$ of it respectively. Generally, it could be arranged effect of different processing methods which used in this study on lowering values of phytic acid, tannins and trypsin inhibitor as follow: dehulled $>$ cooking $>$ roasting $>$ soaking. The values for the antinutrients above were in comparable with the values reported by Jayalaxmi et al. [12], Farinde et al. [31] and Ogechukwu et al. [35].

Table 4. Anti-nutrient contents of lima bean seeds ( $\mathrm{mg} / \mathrm{g}$ on dry weight basis) as affected by different processing methods.

\begin{tabular}{cccccc}
\hline \multirow{2}{*}{ Parameters } & \multicolumn{5}{c}{ Processing methods } \\
\cline { 2 - 6 } & Raw & Cooking & Soaking & Roasting & Dehulled \\
\hline Phytic acid (mg/g) & $8.57 \pm 0.04^{\mathrm{a}}$ & $4.44 \pm 0.03^{\mathrm{d}}$ & $5.75 \pm 0.04^{\mathrm{b}}$ & $5.32 \pm 0.02^{\mathrm{c}}$ & $0.67 \pm 0.01^{\mathrm{e}}$ \\
Tannins (mg/g) & $5.58 \pm 0.02^{\mathrm{a}}$ & $2.53 \pm 0.02^{\mathrm{d}}$ & $4.22 \pm 0.03^{\mathrm{b}}$ & $3.93 \pm 0.03^{\mathrm{c}}$ & $1.72 \pm 0.03^{\mathrm{e}}$ \\
Trypsin inhibitor (mg/g) & $4.28 \pm 0.03^{\mathrm{a}}$ & ND & $1.62 \pm 0.02^{\mathrm{b}}$ & $0.42 \pm 0.02^{\mathrm{c}}$ & ND \\
\hline
\end{tabular}

ND: not detected. Values are means of three replicates \pm standard deviation, number in the same row followed by the same letter are not significantly different at $P \leq 0.05$.

\subsection{Sensory Evaluation of Biscuits}

An important aspect in designing biscuits with improved nutritional quality is 
the maintenance of a product's sensory characteristics because consumers' acceptability remains the key factor which determines the successful application of a newly developed product [36]. Sensory characteristics of biscuits baked are presented in Table 5. The results revealed that, there were no significant difference in biscuit appearance, color, texture and overall acceptability between the control biscuit (CB) and all substitution biscuits raw (RALB), cooked (COLB), soaked (SOLB), roasted (ROLB), and dehulled (DELB). On the other hand, the odor and taste scores decreased significantly in RALB sample (8.75 and 8.45 respectively) compared to control biscuit. In general, it could be observed that using lima bean powder raw or treated (cooked or soaked or roasted or dehulled) in biscuit proportion at level 30\% of replacement did not affect the most sensory characteristics of biscuit.

Table 5. Sensory acceptability scores of biscuits.

\begin{tabular}{|c|c|c|c|c|c|c|}
\hline \multirow{2}{*}{ Parameters } & \multicolumn{6}{|c|}{ Biscuit Samples } \\
\hline & $\mathrm{CB}$ & RALB & COLB & SOLB & ROLB & DELB \\
\hline Appearance (10) & $9.50 \pm 0.70^{\mathrm{a}}$ & $9.40 \pm 0.56^{\mathrm{a}}$ & $9.70 \pm 0.42^{\mathrm{a}}$ & $9.65 \pm 0.41^{\mathrm{a}}$ & $9.35 \pm 0.70^{\mathrm{a}}$ & $9.35 \pm 0.85^{\mathrm{a}}$ \\
\hline Color (10) & $9.60 \pm 0.84^{\mathrm{a}}$ & $9.45 \pm 0.49^{\mathrm{a}}$ & $9.50 \pm 0.52^{\mathrm{a}}$ & $9.50 \pm 0.57^{\mathrm{a}}$ & $9.20 \pm 0.88^{\mathrm{a}}$ & $9.35 \pm 0.70^{\mathrm{a}}$ \\
\hline Odor (10) & $9.70 \pm 0.48^{\mathrm{a}}$ & $8.75 \pm 1.18^{\mathrm{b}}$ & $9.25 \pm 0.63^{\mathrm{ab}}$ & $9.60 \pm 0.65^{a}$ & $9.25 \pm 0.79^{\mathrm{ab}}$ & $9.20 \pm 0.94^{\mathrm{ab}}$ \\
\hline Texture (10) & $8.95 \pm 1.03^{\mathrm{a}}$ & $9.00 \pm 1.02^{\mathrm{a}}$ & $9.05 \pm 0.83^{\mathrm{a}}$ & $9.10 \pm 0.77^{\mathrm{a}}$ & $9.20 \pm 0.78^{\mathrm{a}}$ & $9.20 \pm 0.75^{\mathrm{a}}$ \\
\hline Taste (10) & $9.30 \pm 0.79^{\mathrm{a}}$ & $8.45 \pm 0.93^{\mathrm{b}}$ & $8.70 \pm 0.67^{\mathrm{ab}}$ & $9.00 \pm 0.62^{\mathrm{ab}}$ & $8.65 \pm 0.67^{\mathrm{ab}}$ & $8.85 \pm 0.53^{\mathrm{ab}}$ \\
\hline $\begin{array}{c}\text { Overall } \\
\text { Acceptability (50) }\end{array}$ & $47.05 \pm 2.78^{\mathrm{a}}$ & $45.05 \pm 2.37^{\mathrm{a}}$ & $46.20 \pm 1.49^{\mathrm{a}}$ & $46.85 \pm 1.99^{\mathrm{a}}$ & $45.65 \pm 2.26^{a}$ & $45.95 \pm 2.55^{\mathrm{a}}$ \\
\hline
\end{tabular}

$\mathrm{CB}=$ Control biscuit $(100 \%$ wheat flour $), \mathrm{RALB}=$ Biscuit $(30 \%$ raw lima bean replacement $), \mathrm{COLB}=\mathrm{Bis}-$ cuit $(30 \%$ cooked lima bean replacement), SOLB = Biscuit ( $30 \%$ soaked lima bean replacement), ROLB = Biscuit ( $30 \%$ roasted lima bean replacement), DELB $=$ Biscuit ( $30 \%$ dehulled lima bean replacement). Values are means of ten replicates \pm standard deviation, number in the same row followed by the same letter are not significantly different at $P \leq 0.05$.

\subsection{Physical Properties, Moisture Content and Water Activity $\left(\alpha_{\mathrm{w}}\right)$ of Biscuits}

Table 6 represents the physical characteristics, moisture content and water activity $\left(\alpha_{w}\right)$ of biscuits. It could be observed that, the values of weight were significantly increased in COLB and SOLB compared to CB, however, these values showed insignificant increment in RALB, ROLB and DELB. Also, diameter of all substitution biscuits was significantly increased comparing to control biscuit, the highest diameter value was observed in RALB biscuit as well, thickness value of this biscuit sample was significantly higher than those of CB, SOLB and DELB biscuits. These variations in diameter and thickness between lima biscuits, and the control one were reflected in the spread ratio that stands for a ratio of diameter to height. Spread ratio has long used as an important parameter for determining quality of flour for biscuit production, biscuit with a higher value of spread ratio are more desirable than those with lower value [37] [38]. In the present study spread ratio significantly increased with all substitution in biscuits, 
Table 6. Physical characteristics, moisture content and water activity $\left(\alpha_{\mathrm{w}}\right)$ of biscuits.

\begin{tabular}{ccccccc}
\hline \multirow{2}{*}{ Parameters } & \multicolumn{5}{c}{ Biscuit Samples } \\
\cline { 2 - 7 } & CB & RALB & COLB & SOLB & ROLB & DELB \\
\hline Weight $(\mathrm{g})$ & $9.08 \pm 0.05^{\mathrm{b}}$ & $9.93 \pm 0.03^{\mathrm{ab}}$ & $10.59 \pm 0.03^{\mathrm{a}}$ & $10.31 \pm 0.02^{\mathrm{a}}$ & $10.03 \pm 0.07^{\mathrm{ab}}$ & $9.40 \pm 0.04^{\mathrm{b}}$ \\
Diameter (mm) & $48.00 \pm 0.27^{\mathrm{d}}$ & $55.00 \pm 0.19^{\mathrm{a}}$ & $52.00 \pm 0.15^{\mathrm{c}}$ & $52.00 \pm 0.20^{\mathrm{c}}$ & $53.00 \pm 0.23^{\mathrm{b}}$ & $54.00 \pm 0.22^{\mathrm{ab}}$ \\
Thickness (mm) & $6.53 \pm 0.10^{\mathrm{b}}$ & $7.11 \pm 0.19^{\mathrm{a}}$ & $6.87 \pm 0.13^{\mathrm{ab}}$ & $6.53 \pm 0.11^{\mathrm{b}}$ & $6.93 \pm 0.12^{\mathrm{ab}}$ & $6.60 \pm 0.13^{\mathrm{b}}$ \\
Spread Ratio (D/T) & $7.35 \pm 0.05^{\mathrm{f}}$ & $7.74 \pm 0.07^{\mathrm{c}}$ & $7.57 \pm 0.03^{\mathrm{e}}$ & $7.96 \pm 0.04^{\mathrm{b}}$ & $7.65 \pm 0.02^{\mathrm{d}}$ & $8.18 \pm 0.05^{\mathrm{a}}$ \\
Spread factor (\%) & $100.00 \pm 0.11^{\mathrm{f}}$ & $105.44 \pm 0.07^{\mathrm{c}}$ & $102.99 \pm 0.05^{\mathrm{e}}$ & $108.30 \pm 0.09^{\mathrm{b}}$ & $104.08 \pm 0.07^{\mathrm{d}}$ & $111.29 \pm 0.15^{\mathrm{a}}$ \\
Hardness & $29.49 \pm 0.19^{\mathrm{d}}$ & $40.31 \pm 0.11^{\mathrm{a}}$ & $36.56 \pm 0.20^{\mathrm{c}}$ & $38.95 \pm 0.42^{\mathrm{b}}$ & $41.06 \pm 0.40^{\mathrm{a}}$ & $30.02 \pm 0.15^{\mathrm{d}}$ \\
Moisture (\%) & $3.28 \pm 0.01^{\mathrm{e}}$ & $5.13 \pm 0.07^{\mathrm{b}}$ & $5.78 \pm 0.07^{\mathrm{a}}$ & $4.28 \pm 0.12^{\mathrm{c}}$ & $3.79 \pm 0.01^{\mathrm{d}}$ & $5.89 \pm 0.13^{\mathrm{a}}$ \\
Water activity $\left(\alpha_{\mathrm{w}}\right)$ & $0.283 \pm 0.003^{\mathrm{e}}$ & $0.395 \pm 0.002^{\mathrm{c}}$ & $0.335 \pm 0.001^{\mathrm{d}}$ & $0.414 \pm 0.003^{\mathrm{b}}$ & $0.291 \pm 0.002^{\mathrm{e}}$ & $0.470 \pm 0.001^{\mathrm{a}}$ \\
\hline
\end{tabular}

$\mathrm{CB}=$ Control biscuit $(100 \%$ wheat flour $), \mathrm{RALB}=$ Biscuit $(30 \%$ raw lima bean replacement $), \mathrm{COLB}=$ Biscuit $(30 \%$ cooked lima bean replacement $)$, SOLB $=$ Biscuit $(30 \%$ soaked lima bean replacement), ROLB $=$ Biscuit $(30 \%$ roasted lima bean replacement), DELB $=$ Biscuit $(30 \%$ dehulled lima bean replacement). Values are means of three replicates \pm standard deviation, number in the same row followed by the same letter are not significantly different at $P \leq 0.05$.

this may be probably due to reduce the viscosity of biscuits dough as a result of addition raw or treated lima bean even though the protein content is high. Also, spread ratio could have been affected by deficiency of gluten content. These results agree with [39] [40]. In addition to spread factor of all substitution biscuit samples were increased comparing with control biscuit.

Hardness parameter represents the force required by the cutting probe to penetrate the biscuit and cut it into halves. It could, therefore, be understood as the necessary force to be employed for biting the biscuit [41]. The obtained results for the hardness parameter in Table 6 showed that non-significant difference between CB and DELP biscuits. Meanwhile, the hardness values of all other substituted biscuits were increased significantly compared with control biscuit. Thus, it can be concluded that both RALB, COLB, SOLB and ROLB biscuits would be suitable to maintain its shape during transportation. The hardness in biscuits is much influenced by the interaction between the different ingredients. The increase in hardness may be attributed to increase fiber or protein contents in raw, cooked, soaked and roasted lima bean powders. These results are on the same line with Noor Aziah et al. [42] who found that cookies hardness increased with substitution wheat flour with mung bean or chickpea flour also, with Rojo-Poveda et al. [41] and Becker et al. [43] who stated that hardness of biscuits increase with increase in fiber or protein contents of biscuits.

Moisture content of the substitution biscuits ranged from 3.79\% for ROLB biscuit to $5.89 \%$ for DELB biscuit compared with $3.28 \%$ for CB biscuit. The significant increase in moisture content may be due to the difference in components and water holding capacity for each sample. A similar trend for moisture content was noticed in water activity $\left(\alpha_{\mathrm{w}}\right)$ where DELB biscuit had the highest value (0.470) and ROLB biscuit had the lowest value (0.291). The moisture content of all substitution biscuit samples was low enough $(<10 \%)$ to reduce the possibility of microbial attack and would increase shelf stability of biscuit sam- 
ples also, $\alpha_{\mathrm{w}}$ values are below the recommended $\alpha_{\mathrm{w}}$ requirements for facilitates diverse microbial growth $\left(\alpha_{\mathrm{w}}>0.80\right)$ [44] [45].

\subsection{Chemical Composition of Biscuits}

Chemical composition, energy and mineral content of different biscuit samples are shown in Table 7. Protein, ash and crude fiber contents were significantly increased in all substitution biscuits compared with control biscuit (CB). The highest significant value of protein was detected in DELB biscuit, while the highest significant values of ash and crude fiber were observed in ROLB biscuit. For fat content, DELB had the highest content followed by SOLB biscuit. On the other hand, total carbohydrates and energy values significantly decreased in all substitution of biscuits which made by replacing wheat flour with raw or treated lima beans. The values of energy for biscuit samples ranked as follows: CB biscuit $>$ DELB biscuit $>$ SOLB biscuit $>$ COLB biscuit $>$ ROLB biscuit $>$ RALB biscuit.

Similarly, Noor Aziah et al. [42] reported a decreasing trend in the energy value from 509.11 - 503.48 and 509.11 - $505.64 \mathrm{kcal} / 100 \mathrm{~g}$ for cookies incorporated with mung bean or chickpea, respectively.

Table 7. Chemical Composition (\%) and mineral contents (mg/100g) of biscuits on dry weight basis.

\begin{tabular}{|c|c|c|c|c|c|c|}
\hline \multirow{2}{*}{ Parameters } & \multicolumn{6}{|c|}{ Biscuit Samples } \\
\hline & $\mathrm{CB}$ & RALB & COLB & SOLB & ROLB & DELB \\
\hline Protein & $9.84 \pm 0.03^{\mathrm{f}}$ & $13.14 \pm 0.3^{\mathrm{b}}$ & $12.77 \pm 0.02^{\mathrm{e}}$ & $12.96 \pm 0.01^{\mathrm{d}}$ & $13.03 \pm 0.03^{c}$ & $14.23 \pm 0.02^{\mathrm{a}}$ \\
\hline Ash & $0.74 \pm 0.03^{\mathrm{e}}$ & $1.49 \pm 0.02^{\mathrm{b}}$ & $1.42 \pm 0.01^{\mathrm{c}}$ & $1.43 \pm 0.03^{\mathrm{c}}$ & $1.53 \pm 0.02^{\mathrm{a}}$ & $1.34 \pm 0.01^{\mathrm{d}}$ \\
\hline Fat & $19.96 \pm 0.05^{c}$ & $19.22 \pm 0.02^{\mathrm{e}}$ & $19.74 \pm 0.03^{\mathrm{d}}$ & $20.18 \pm 0.02^{\mathrm{b}}$ & $19.94 \pm 0.03^{c}$ & $20.51 \pm 0.02^{\mathrm{a}}$ \\
\hline Crude fiber & $0.55 \pm 0.05^{\mathrm{f}}$ & $1.67 \pm 0.02^{\mathrm{b}}$ & $1.46 \pm 0.01^{\mathrm{c}}$ & $1.34 \pm 0.01^{\mathrm{d}}$ & $1.83 \pm 0.02^{\mathrm{a}}$ & $0.92 \pm 0.02^{\mathrm{e}}$ \\
\hline *Total carbohydrates & $68.91 \pm 0.05^{\mathrm{a}}$ & $64.48 \pm 0.03^{c}$ & $64.61 \pm 0.02^{\mathrm{b}}$ & $64.09 \pm 0.03^{\mathrm{d}}$ & $63.67 \pm 0.07^{\mathrm{e}}$ & $63.00 \pm 0.05^{\mathrm{f}}$ \\
\hline Energy (Kcal/100g) & $494.64 \pm 0.15^{\mathrm{a}}$ & $483.46 \pm 0.19^{f}$ & $487.18 \pm 0.12^{\mathrm{d}}$ & $489.82 \pm 0.17^{\mathrm{c}}$ & $486.26 \pm 0.15^{\mathrm{e}}$ & $493.51 \pm 0.13^{\mathrm{b}}$ \\
\hline Soluble dietary fiber (SDF) & $1.62 \pm 0.01^{\mathrm{f}}$ & $3.92 \pm 0.01^{\mathrm{d}}$ & $4.64 \pm 0.01^{\mathrm{b}}$ & $5.24 \pm 0.01^{\mathrm{a}}$ & $4.15 \pm 0.02^{\mathrm{c}}$ & $3.72 \pm 0.01^{\mathrm{a}}$ \\
\hline Insoluble dietary fiber (IDF) & $2.15 \pm 0.01^{\mathrm{f}}$ & $8.23 \pm 0.02^{\mathrm{d}}$ & $11.04 \pm 0.03^{\mathrm{b}}$ & $11.12 \pm 0.02^{\mathrm{a}}$ & $10.82 \pm 0.02^{c}$ & $4.93 \pm 0.02^{\mathrm{e}}$ \\
\hline Calcium & $56.49 \pm 0.01^{\mathrm{f}}$ & $100.85 \pm 0.02^{\mathrm{a}}$ & $99.92 \pm 0.03^{\mathrm{b}}$ & $98.72 \pm 0.03^{c}$ & $95.78 \pm 0.02^{\mathrm{d}}$ & $93.37 \pm 0.02^{\mathrm{e}}$ \\
\hline Phosphorus & $160.53 \pm 0.03^{f}$ & $237.31 \pm 0.01^{\mathrm{a}}$ & $210.12 \pm 0.02^{\mathrm{e}}$ & $221.15 \pm 0.01^{\mathrm{d}}$ & $227.84 \pm 0.01^{\mathrm{b}}$ & $225.88 \pm 0.02^{c}$ \\
\hline Iron & $1.92 \pm 0.02^{\mathrm{e}}$ & $4.58 \pm 0.02^{\mathrm{a}}$ & $3.13 \pm 0.01^{c}$ & $3.83 \pm 0.03^{\mathrm{b}}$ & $2.47 \pm 0.02^{\mathrm{d}}$ & $2.46 \pm 0.01^{\mathrm{d}}$ \\
\hline Magnesium & $73.35 \pm 0.02^{\mathrm{f}}$ & $146.35 \pm 0.02^{\mathrm{a}}$ & $130.83 \pm 0.03^{c}$ & $136.37 \pm 0.02^{\mathrm{b}}$ & $129.94 \pm 0.01^{\mathrm{d}}$ & $126.72 \pm 0.02^{\mathrm{e}}$ \\
\hline Sodium & $82.87 \pm 0.02^{c}$ & $79.26 \pm 0.01^{\mathrm{d}}$ & $83.72 \pm 0.02^{\mathrm{b}}$ & $64.42 \pm 0.02^{\mathrm{f}}$ & $84.93 \pm 0.02^{\mathrm{a}}$ & $79.06 \pm 0.01^{\mathrm{e}}$ \\
\hline Potassium & $159.33 \pm 0.03^{\mathrm{f}}$ & $443.12 \pm 0.01^{\mathrm{b}}$ & $439.21 \pm 0.01^{\mathrm{d}}$ & $442.02 \pm 0.02^{c}$ & $444.04 \pm 0.01^{\mathrm{a}}$ & $408.83 \pm 0.02^{\mathrm{e}}$ \\
\hline Copper & $0.37 \pm 0.02^{\mathrm{f}}$ & $0.83 \pm 0.02^{b}$ & $0.61 \pm 0.01^{\mathrm{d}}$ & $0.74 \pm 0.01^{\mathrm{c}}$ & $1.15 \pm 0.01^{\mathrm{a}}$ & $0.52 \pm 0.03^{\mathrm{e}}$ \\
\hline Manganese & $0.47 \pm 0.02^{\mathrm{b}}$ & $0.53 \pm 0.01^{\mathrm{a}}$ & $0.48 \pm 0.02^{\mathrm{b}}$ & $0.53 \pm 0.02^{\mathrm{a}}$ & $0.47 \pm 0.02^{\mathrm{b}}$ & $0.52 \pm 0.03^{\mathrm{a}}$ \\
\hline Zinc & $1.11 \pm 0.01^{\mathrm{e}}$ & $1.51 \pm 0.01^{\mathrm{a}}$ & $1.42 \pm 0.01^{\mathrm{c}}$ & $1.41 \pm 0.02^{c}$ & $1.45 \pm 0.02^{\mathrm{b}}$ & $1.37 \pm 0.02^{\mathrm{d}}$ \\
\hline
\end{tabular}

$\mathrm{CB}=$ Control biscuit ( $100 \%$ wheat flour), RALB = Biscuit ( $30 \%$ raw lima bean replacement), COLB = Biscuit ( $30 \%$ cooked lima bean replacement), SOLB = Biscuit ( $30 \%$ soaked lima bean replacement), ROLB = Biscuit ( $30 \%$ roasted lima bean replacement), DELB = Biscuit ( $30 \%$ dehulled lima bean replacement). Values are means of three replicates \pm standard deviation, number in the same row followed by the same letter are not significantly different at $P \leq 0.05$. *Total carbohydrates calculated by differences. 
Soluble Dietary Fiber (SDF), Insoluble Dietary Fiber (IDF) and Total Dietary Fiber (TDF) contents of all substitution biscuit samples were increased compared with control biscuit.

From the same Table, it could be concluded that substitution of wheat flour with raw or treated lima bean powders caused a significant increase in the all under-investigation minerals content except sodium and manganese.

The increment in protein, ash, crude fiber, SDF, IDF, TDF and mineral contents such as calcium, phosphorus, iron, magnesium, potassium, copper and zinc may be due to the higher content of these components in raw or/treated lima bean powder as shown in Table 2. These results were agreed with Kathirvel and Kumudha [6], Bonita et al. [7] and Jayalaxmi et al. [12] who showed that lima beans are a good source of nutrients such as proteins, crude fiber, dietary fiber and minerals.

\subsection{Amino Acids Profile of CB \& RALB Biscuits}

Amino acids contents, Biological Value (BV) and Chemical Score (CS) of CB and RALB biscuits are given in Table 8. Data showed that RALB biscuit had the highest quantity of all essential amino acids, but it was deficient in methionine and cystine. Also, RALB biscuit had higher total essential amino acids content (43.81 $\mathrm{g} / 100 \mathrm{~g}$ protein) compared to those in CB biscuit ( $38.49 \mathrm{~g} / 100 \mathrm{~g}$ protein). However, glutamic, glycine, alanine, proline and total non-essential amino acids were higher in CB biscuit than in RALB biscuit. Biological value (BV) was higher in RALB biscuit (80.62\%) than CB biscuit (68.09\%). This result is due to the higher lysine content of RALB biscuit (4.62). Higher lysine content was associated with increasing of BV Kohajdova et al. [46]. Also, RALB biscuit had the highest CS for all essential amino acids, except methionine and cystine, lysine was the limiting amino for children and adult in CB biscuit and for children only in RALB biscuit. But, chemical score of lysine was improved from $66.88 \%$ for children in CB biscuit to $96.25 \%$ in RALB biscuit. Finally, from the above-mentioned results, it can be concluded that replacement of wheat flour with $30 \%$ lima bean powder in preparing biscuit proved to have high BV and CS.

\subsection{Anti-Nutritional Factors of Biscuits}

Table 9 shows the remaining quantities of phytic acid, tannins, and trypsin inhibitor in the produced biscuits. The results showed significant differences between different biscuit samples in the contents of phytic acid, tannins, and trypsin inhibitor. The values of phytic acid and tannins ranged between 0.52 to 1.02 and 0.11 to $0.26 \mathrm{mg} / \mathrm{g}$, respectively. The lowest significant value $(0.52 \mathrm{mg} / \mathrm{g})$ of phytic acid was found in DELB biscuit, while RALB biscuit had the highest significant values of phytic and tannins (1.02 and $0.26 \mathrm{mg} / \mathrm{g}$, respectively). Meanwhile, the lowest value of tannins $(0.11 \mathrm{mg} / \mathrm{g})$ was for CB biscuit. Trypsin inhibitor was detected only in RALB $(0.18 \mathrm{mg} / \mathrm{g})$ and SOLB $(0.05 \mathrm{mg} / \mathrm{g})$ biscuits. The phytic and tannins levels of all substitution biscuit samples obtained in this 
Table 8. Amino acids contents of CB and RALB biscuits (g/100 gm protein).

\begin{tabular}{|c|c|c|c|c|c|c|c|c|}
\hline \multirow{3}{*}{ Amino Acids } & \multirow{3}{*}{$\mathrm{CB}$} & \multirow{3}{*}{ RALB } & \multicolumn{2}{|c|}{ Ref. Pattern FAO (2011) } & \multicolumn{4}{|c|}{ Chemical Score \% (CS) } \\
\hline & & & \multirow{2}{*}{ Children } & \multirow{2}{*}{ Adult } & \multicolumn{2}{|c|}{$\mathrm{CB}$} & \multicolumn{2}{|c|}{ RALB } \\
\hline & & & & & Children & Adult & Children & Adult \\
\hline \multicolumn{9}{|l|}{ Essential amino acids } \\
\hline Threonine & 3.40 & 3.99 & 2.50 & 2.30 & 136.00 & 147.83 & 159.60 & 173.48 \\
\hline Valine & 4.80 & 5.54 & 4.00 & 3.90 & 120.00 & 123.08 & 138.50 & 142.05 \\
\hline Isoleucine & 4.00 & 4.33 & 3.00 & 3.00 & 133.33 & 133.33 & 144.33 & 144.33 \\
\hline Leucine & 7.32 & 7.80 & 6.10 & 5.90 & 120.00 & 124.07 & 127.87 & 132.20 \\
\hline Phenylalanine & 5.03 & 5.22 & - & - & - & - & - & - \\
\hline Tyrosine & 3.20 & 4.33 & - & - & - & - & - & - \\
\hline Phenylalanine + Tyrosine & 8.23 & 9.55 & 4.10 & 3.80 & 200.73 & 216.58 & 232.93 & 251.32 \\
\hline Lysine & 3.21 & 4.62 & 4.80 & 4.50 & 66.88 & 71.33 & 96.25 & 102.67 \\
\hline Methionine & 2.40 & 2.26 & - & - & - & - & - & - \\
\hline Cystine & 2.70 & 2.52 & - & - & - & - & - & - \\
\hline Methionine + Cystine & 5.10 & 4.78 & 2.30 & 2.20 & 221.74 & 231.82 & 207.83 & 217.27 \\
\hline Histidine & 2.43 & 3.20 & 1.60 & 1.50 & 151.88 & 162.00 & 200.00 & 213.33 \\
\hline TEAA & 38.49 & 43.81 & - & - & - & - & - & - \\
\hline Biological value\% (BV) & 68.09 & 80.62 & - & - & - & - & - & - \\
\hline \multicolumn{9}{|l|}{ Non-essential amino acids } \\
\hline Aspartic & 6.51 & 8.28 & - & - & - & - & - & - \\
\hline Serine & 5.10 & 5.47 & - & - & - & - & - & - \\
\hline Glutamic & 28.87 & 23.04 & - & - & - & - & - & - \\
\hline Glycine & 3.73 & 3.52 & - & - & - & - & - & - \\
\hline Alanine & 3.90 & 3.64 & - & - & - & - & - & - \\
\hline Arginine & 4.10 & 4.78 & - & - & - & - & - & - \\
\hline Proline & 9.30 & 7.46 & - & - & - & - & - & - \\
\hline TNEAA & 61.51 & 56.19 & - & - & - & - & - & - \\
\hline
\end{tabular}

$\mathrm{CB}=$ Control biscuit $(100 \%$ wheat flour $), \mathrm{RALB}=$ Biscuit $\left(30 \%\right.$ raw lima bean replacement). ${ }^{\star}$ Tryptophan was not determined. ${ }^{*}$ TEAA $=$ Total essential amino acids, TNEAA $=$ Total non-essential amino acids. ( $\mathrm{g} / 100 \mathrm{~g}$ protein $)$.

Table 9. Anti-nutrient contents of biscuits $(\mathrm{mg} / \mathrm{g})$ on dry weight basis.

\begin{tabular}{ccccccc}
\hline & \multicolumn{9}{c}{ Biscuits Samples } \\
\cline { 2 - 7 } Parameters & CB & RALB & COLB & SOLB & ROLB & DELB \\
\hline Phytic acid (mg/g) & $0.76 \pm 0.05^{\mathrm{e}}$ & $1.02 \pm 0.04^{\mathrm{a}}$ & $0.89 \pm 0.01^{\mathrm{d}}$ & $0.98 \pm 0.03^{\mathrm{b}}$ & $0.93 \pm 0.02^{\mathrm{c}}$ & $0.52 \pm 0.01^{\mathrm{f}}$ \\
Tannins (mg/g) & $0.11 \pm 0.01^{\mathrm{f}}$ & $0.26 \pm 0.03^{\mathrm{a}}$ & $0.18 \pm 0.05^{\mathrm{d}}$ & $0.22 \pm 0.01^{\mathrm{b}}$ & $0.21 \pm 0.02^{\mathrm{c}}$ & $0.13 \pm 0.03^{\mathrm{e}}$ \\
Trypsin inhibitor $(\mathrm{mg} / \mathrm{g})$ & $\mathrm{ND}$ & $0.18 \pm 0.01^{\mathrm{a}}$ & $\mathrm{ND}$ & $0.05 \pm 0.01^{\mathrm{b}}$ & $\mathrm{ND}$ & $\mathrm{ND}$ \\
\hline
\end{tabular}

$\mathrm{CB}=$ Control biscuit $(100 \%$ wheat flour $), \mathrm{RALB}=$ Biscuit $(30 \%$ raw lima bean replacement), COLB = Biscuit ( $30 \%$ cooked lima bean replacement), SOLB $=$ Biscuit ( $30 \%$ soaked lima bean replacement), ROLB = Biscuit ( $30 \%$ roasted lima bean replacement), DELB = Biscuit ( $30 \%$ dehulled lima bean replacement). Values are means of three replicates \pm standard deviation, number in the same row followed by the same letter are not significantly different at $P \leq 0.05$. 
study were lower than the range (70.30 to $108.52 \mathrm{mg} / 100 \mathrm{~g}$ for phytic) and (32.54 to $69.72 \mathrm{mg} / 100 \mathrm{~g}$ for tannins) reported for wheat-cowpea biscuit by Yilma and Admassu [47] and 69.7 to $244 \mathrm{mg} / 100 \mathrm{~g}$ for phytic reported for wheat-fenugreek biscuits by Hoda and Jood [48]. As well, values of phytic acid, tannins and trypsin inhibitor in CB biscuit were nearly agreed with that reported by Ziena et al. [49]. Finally, it can be concluded that the primary technological treatments on seeds and different steps for making biscuit caused substantial reductions in antinutrients the same finding was noticed by Ziena et al. [49] and Chiremba et al. [50].

\section{Conclusion}

From this study it could be concluded that Lima bean appears to be a good source of some nutrients such as: proteins, dietary fiber, minerals and Essential Amino Acids (EAA). On the other hand, Lima bean contained anti-nutritional factors, i.e. phytic acid, tannins and trypsin inhibitor which partially or totally affected by common processing methods (cooking, soaking, roasting and dehulling). Good quality biscuit with acceptable sensory, physical, chemical characteristics and nutrition value could be produced by incorporating 30\% Lima bean powder with $70 \%$ wheat flour $72 \%$ extraction rate. The biscuits had significant improvement in protein, dietary fiber, minerals and EAA which in most cases, limits covered the recommended requirements of FAO/WHO. Therefore, it can be recommended that the incorporation of Lima bean to whet flour will enhance the nutritional composition of the biscuits and will also help to reduce dependence on wheat flour.

\section{Conflicts of Interest}

The author declares no conflicts of interest regarding the publication of this paper.

\section{References}

[1] Brink, M. and Belay, G. (2006) Plant Resources of Tropical Africa 1. Cereals and Pulses. PROTA Foundation/Backhuys Puplisher/CTA, Wageningen, 141, 143.

[2] Ishaya, F.A. and Aletor, O. (2019) Nutritive Potential and Functional Attributes of Lima Bean (Phaseolus Lunatus) and Pigeon Pea (Cajan Cajanus) Protein Isolates. Journal of Integrative Food Sciences \& Nutrition, 3, 1-6. http://www.scientonline.org

[3] Ibeabuchi, J.C, Okafor, D.C., Ahaotu, N.N., Eluchie, C.N., Agunwah, J., M., Chukwu, M.N. and Amandikwa, C. (2019) Effect of Dehulling on Proximate Composition and Functional Properties of Lima Bean (Phaseolus lunatus) Grown in Enugu State. Journal of Food Research, 8, 116-121. https://doi.org/10.5539/jfr.v8n2p116

[4] Badawy, A.S.M., Ismail, F.S. and Salem, A.K. (2019) Effect of Sowing Dates and Potassium Fertilizer Rates on Seed Yield of Lima Bean CV. (Phaseolus vulgaris L.). Journal of Plant Production, 10, 45-52. https://dx.doi.org/10.21608/jpp.2019.36202

[5] Apata, D.F. and Ologhobo, A.A. (1997) Trypsin Inhibitor and the Other Anti-Nutritional Factors in Tropical Legume Seeds. Tropical Science, 37, 52-59. 
[6] Kathirvel, P. and Kumudha, P. (2011) A Comparative Study on the Chemical Composition of Wild and Cultivated Germplasm of Phaseolus lunatus L. International Journal of Applied Biology and Pharmaceutical Technology, 2, 296-305.

[7] Bonita, L.C., Shantibala Devi, G.A. and Brajakishor Singh, C.H. (2020) Lima Bean (Phaseolus Lunatus L.) - A Health Perspective. International Journal of Scientific \& Technology Research, 9, 5638-5649.

[8] Sharma, A. and Sehgal, S. (1992) Effect of Processing and Cooking on the Antinutritional Factors of Faba Bean (Vicia faba). Food Chemistry, 43, 383-385. https://doi.org/10.1016/0308-8146(92)90311-O

[9] Ezeagu, E.I. and Ibegbu, M.D. (2010) Biochemical Composition and Nutritional Potential of Ukpa: A Variety of Tropical Lima Beans (Phaseolus lunatus) from Nigeria. Polish Journal of Food and Nutrition Sciences, 60, 231-235.

[10] Yellavila, S.B., Agbenorhevi, J.K., Asibuo, J.Y. and Sampson, G.O. (2015) Proximate Composition, Minerals Content and Functional Properties of Five Lima Bean Accessions. Journal of Food Security, 3, 69-74.

[11] D’souza, M.R. (2013) Effect of Traditional Processing Methods on Nutritional Quality of Field Bean. Advances in Bioresearch, 14, 29-33.

[12] Jayalaxmi, B., Vijayalakshmi, D., Usha, R., Revanna, M.L., Chandru, R. and Ramanjini Gowda, P.H. (2016) Effect of Different Processing Methods on Proximate, Mineral and Antinutrient Content of Lima Bean (Phaseolus lunatus) Seeds. Legume Research-An International Journal, 39, 543-549.

https://doi.org/10.18805/lr.v0iOF.7108

[13] Amer, A.A., EL-Beltagi, H.S., Ali, R.F.M., Mousa, S.M. and Abdel-Rahim, E. (2019) The Effects of Wheat Flour and Barley Flour on the Quality and Properties of Biscuits Colored with Synthetic and Natural Colorants. Notulae Scientia Biologicae, 11, 30-38. https://doi.org/10.15835/nsb11110408

[14] Ahmad, S. and Ahmed, M. (2014) A Review on Biscuit, a Largest Consumed Processed Product in India, Its Fortification and Nutritional Important. International Journal of Science Inventions Today, 3, 169-186.

[15] Klunklin, W. and Savage, G. (2018) Biscuits: A Substitution of Wheat Flour with Purple Rice Flour. Advances in Food Science and Engineering, 2, 81-97. https://doi.org/10.22606/afse.2018.23001

[16] Adebayo, S.F. and Okoli, E.C. (2017) Production and Evaluation of Biscuits from Lima Bean (Phaseolus Lunatus), Sorghum and Wheat Flour Blends. Journal of Environmental Science, Toxicology and Food Technology, 11, 44-48.

[17] Singh, N. (2017) Pulses: An Overview. Journal of Food Science and Technology, 54, 853-857. https://doi.org/10.1007/s13197-017-2537-4

[18] Youssef, M.M.A. (1978) Study of Factors Affecting the Cookability of Faba Bean (Vicia faba L.). Ph.D. Thesis, Faculty of Agriculture. Alexandria University, Alexandria.

[19] Analysis Association of Official Analytical Chemists (2012) Official Method of Analysis Association of Official Analytical Chemists. 19th Edition, Analysis Association of Official Analytical Chemists, Washington DC.

[20] Analysis Association of Official Analytical Chemists (1990) Official Method of Analysis Association of Official Analytical Chemists. 13th Edition, Analysis Association of Official Analytical Chemists, Gaithersburg.

[21] Prosky, L., Asp, N.G., Schweizer, T., Devries, J.W. and Furda, I. (1988) Determination of Insoluble and Soluble and Total Dietary Fiber in Food Products: Interlabo- 
ratory Study. Journal of Association of Official Analytical Chemists, 71, 1017-1023. https://doi.org/10.1093/jaoac/71.5.1017

[22] Food and Agriculture Organization of the United Nations (2011) Dietary Protein Quality Evaluation in Human Nutrition. Report of FAO Expert Consultation, Auckland, 31 March-2 April 2011, 27.

[23] Eggum, B.O., Villegas, E.F. and Vasal, S.K. (1979) Progress in Protein Quality of Maize. Journal of the Science of Food and Agriculture, 30, 1148-1153. https://doi.org/10.1002/jsfa.2740301206

[24] Wheeler, E.L. and Ferrel, R.E. (1971) A Method for Phytic Acid Determination in Wheat and Wheat Fractions. Cereal Chemistry, 48, 312-320.

[25] Price, M.L., Van Scoyoc, S. and Butler, L.G. (1978) A Critical Evaluation of Vanillin Reaction as an Assay for Tannin in Sorghum Grain. Journal of Agricultural and Food Chemistry, 26, 1214-1218. https://doi.org/10.1021/jf60219a031

[26] Hamerstrand, G.E., Black, L.T. and Glover, J.D. (1981) Trypsin Inhibitors in Soy Products: Modification of the Standard Analytical Procedure. Cereal Chemistry, 58, 42-45.

[27] Sayed, A.M.A. (2011) Biochemical and Technological Studies on Barley Talbina. M.Sc. Thesis, Faculty of Agriculture, Assiut University, Assiut.

[28] Alsenaien, W.A., Alamer, R.A., Tang, Z.X., Albahrani, S.A., Al-Ghannam, M.A. and Aleid, S.M. (2015) Substitution of Sugar with Dates Powder and Dates Syrup in Cookies Making. Advance Journal of Food Science and Technology, 1, 8-13. https://doi.org/10.19026/ajfst.8.1455

[29] Manohar, R.S. and Rao, P.H. (1997) Effect of Mixing Period and Additives on the Rheological Characteristics of Dough and Quality of Biscuits. Journal of Cereal Science, 25, 197-206. https://doi.org/10.1006/jcrs.1996.0081

[30] Adeparusi, E.O. (2001) Effect of Processing on the Nutrients and Anti-Nutrients of Lima Bean (Phaseolus lunatus L.) Flour. Food/ Nahrung, 45, 94-96. https://doi.org/10.1002/1521-3803(20010401)45:2\%3C94::AID-FOOD94\%3E3.0.CO i2-E

[31] Farinde, E.O., Olanipekun, O.T. and Olasupo, R.B. (2018) Nutritional Composition and Antinutrients Content of Raw and Processed Lima Bean (Phaseolus lunatus). Annals. Food Science and Technology, 19, 250-264.

[32] Agiang, M.A., Umoh, I.B, Essien, A.I. and Eteng, M.U. (2010) Nutrient Changes and Antinutrient Contents of Beniseed and Beniseed Soup during Cooking Using a Nigerian Traditional Method. Pakistan Journal of Biological Sciences, 13, 1011-1015. https://doi.org/10.3923/pjbs.2010.1011.1015

[33] Mortuza, G., Hannan, A. and Tzen, J.T.C. (2009) Chemical Composition and Functional Properties of Vicia faba L. from Bangladesh. Bangladesh Journal of Botany, 38, 93-97. https://doi.org/10.3329/bjb.v38i1.5129

[34] Seidu, K.T., Osundahunsi, O.F. and Osamudiamen, P.M. (2018) Nutrients Assessment of Some Lima Bean Varieties Grown in Southwest Nigeria. International Food Research Journal, 25, 848-853.

[35] Ogechukwu, O. and Ikechukwu, O.J. (2017) Effect of Heat Processing Treatments on the Nutrient and Anti-Nutrient Contents of Lima Bean (Phaseolus lunatus) Flour. International Journal of Food Science and Nutrition, 2, 13-17.

[36] Chinma, C.E., James, S., Imam, H., Ocheme, O.B., Anuonye, J.C. and Yakubu, C.M. (2011) Physicochemical and Sensory Properties, and in-Vitro Digestibility of Biscuits Made from Blends of Tigernut (Cyperus esculentus) and Pigeon Pea (Cajanus 
cajan). Nigerian Journal of Nutritional Sciences, 32, 55-62.

https://doi.org/10.4314/njns.v32i1.67816

[37] Adeola, A.A. and Ohizua, E.R. (2018) Physical, Chemical, and Sensory Properties of Biscuits Prepared from Flour Blends of Unripe Cooking Banana, Pigeon Pea, and Sweet Potato. Food Science \& Nutrition, 6, 532-540.

https://doi.org/10.1002/fsn3.590

[38] Inyang, U.E., Danial, E.A. and Bello, F.A. (2018) Production and Quality Evaluation of Functional Biscuits from Whole Wheat Flour Supplemented with Acha (Fonio) and Kidney Bean Flours. Asian Journal of Agriculture and Food Science, 6, 193-201. https://doi.org/10.24203/ajafs.v6i6.5573

[39] Chauhan, A., Saxena, D.C. and Singh, S. (2016) Physical, Textural and Sensory Characteristics of Wheat and Amaranth Flour Blend Cookies. Cogent Food \& Agriculture, 2, Article ID: 1125773. https://doi.org/10.1080/23311932.2015.1125773

[40] Ola, S.I. (2018) Utilization of Sorghum, Broken Rice and White Beans Flours for Producing High Nutritional Value and High-Quality Gluten-Free Biscuits. Current Science International, 6, 670-683.

[41] Rojo-Poveda, O., Barbosa-Pereira, L., Orden, D., Stévigny, C., Zeppa, G. and Bertolino, M. (2020) Physical Properties and Consumer Evaluation of Cocoa Bean ShellFunctionalized Biscuits Adapted for Diabetic Consumers by the Replacement of Sucrose with Tagatose. Foods, 9, Article No. 814. https://doi.org/10.3390/foods9060814

[42] Noor Aziah, A.A., Mohamad Noor, A.Y. and Ho, L.-H. (2012) Physicochemical and Organoleptic Properties of Cookies Incorporated with Legume Flour. International Food Research Journal, 19, 1539-1543.

[43] Becker, F.S., Damiani, C., Machado de Melo, A.A., Borges, P.R.S. and Vilas Boas, E. V. (2014) Incorporation of Buriti Endocarp Flour in Gluten-Free Whole Cookies as Potential Source of Dietary Fiber. Plant Foods for Human Nutrition, 69, 344-350. https://doi.org/10.1007/s11130-014-0440-y

[44] Sharma, S. and Riar, C.S. (2020) Effect of Storage Period and Packaging Materials on Textural, Phenolic, Antioxidant Properties of Cookies Made from Raw and Germinated Minor Millet Blends Flour. Annals Food Science and Technology, 21, 74-85.

[45] Ikuomola, D.S., Otutu, O.L. and Oluniran, D.D. (2017) Quality Assessment of Cookies Produced from Wheat Flour and Malted Barley (Hordeum vulgare) Bran Blends. Cogent Food \& Agriculture, 3, Article ID: 1293471. https://doi.org/10.1080/23311932.2017.1293471

[46] Kohajdová, Z., Karovičová, J. and Schmidt, Š. (2011) Lupin Composition and Possible Use in Bakery-A Review. Czech Journal of Food Sciences, 29, 203-211. https://doi.org/10.17221/252/2009-CJFS

[47] Yilma, M.S. and Admassu, S. (2019) Product Development and Quality Evaluation of Biscuit and Ready-to-Eat Snack from Cowpea-Wheat Flour Blends. Advances in Food Technology and Nutritional Sciences, 5, 92-106. https://doi.org/10.17140/AFTNSOJ-5-161

[48] Hooda, S. and Jood, S. (2005) Organoleptic and Nutritional Evaluation of Wheat Biscuits Supplemented with Untreated and Treated Fenugreek Flour. Food Chemistry, 90, 427-435. https://doi.org/10.1016/j.foodchem.2004.05.006

[49] Ziena, H.M., Shamsia1, S.M., Mahgoub, S.A. and Emara, M.A. (2019) Nutritious Biscuits for Celiac Patients: Effect of Different Cereals and Legumes Blends. Alexandria Science Exchange Journal, 40, 340-346. 
https://doi.org/10.21608/asejaiqjsae.2019.36524

[50] Chiremba, C., Taylor, J.R.N. and Duodu, K.G. (2009) Phenolic Content, Antioxidant Activity, and Consumer Acceptability of Sorghum Cookies. Cereal Chemistry, 86, 590-594. https://doi.org/10.1094/CCHEM-86-5-0590 